\title{
Comparison of lodgepole and jack pine resin chemistry: implications for range expansion by the mountain pine beetle, Dendroctonus ponderosae (Coleoptera: Curculionidae)
}

The mountain pine beetle, [i]Dendroctonus ponderosae[i], is a significant pest of lodgepole pine in British Columbia $(\mathrm{BC})$, where it has recently reached an unprecedented outbreak level. Although it is native to western North America, the beetle can now be viewed as a native invasive because for the first time in recorded history it has begun to reproduce in native jack pine stands within the North American boreal forest. The ability of jack pine trees to defend themselves against mass attack and their suitability for brood success will play a major role in the success of this insect in a putatively new geographic range and host. Lodgepole and jack pine were sampled along a transect extending from the beetle's historic range (central BC) to the newly invaded area east of the Rocky Mountains in north-central Alberta $(A B)$ in Canada for constitutive phloem resin terpene levels. In addition, two populations of lodgepole pine (BC) and one population of jack pine $(A B)$ were sampled for levels of induced phloem terpenes. Phloem resin terpenes were identified and quantified using gas chromatography.

Significant differences were found in constitutive levels of terpenes between the two species of pine. Constitutive $\alpha$-pinene levels - a precursor in the biosynthesis of components of the aggregation and antiaggregation pheromones of mountain pine beetle - were significantly higher in jack pine. However, lower constitutive levels of compounds known to be toxic to bark beetles, e.g., 3-carene, in jack pine suggests that this species could be poorly defended. Differences in wounding-induced responses for phloem accumulation of five major terpenes were found between the two 
populations of lodgepole pine and between lodgepole and jack pine. The mountain pine beetle will face a different constitutive and induced phloem resin terpene environment when locating and colonizing jack pine in its new geographic range, and this may play a significant role in the ability of the insect to persist in this new host. 
Erin L. Clark ${ }^{1 *}$, Caitlin Pitt ${ }^{1}$, Allan L. Carroll ${ }^{2}$, B. Staffan Lindgren ${ }^{1}$, and Dezene P.W. Huber ${ }^{1}$

${ }^{1}$ Ecosystem Science and Management Program, University of Northern British Columbia, 3333 University Way, Prince George, BC, V2N 4Z9

${ }^{2}$ Department of Forest and Conservation Sciences, University of British Columbia, 2424 Main Mall, Vancouver, British Columbia, V6T $1 Z 4$

*correspondence to eclark1@unbc.ca

Key Words - Secondary metabolites, terpenes, Coleoptera, Curculionidae, Scolytinae, plant defense, bark beetles. 


\section{INTRODUCTION}

The primary host of the mountain pine beetle, Dendroctonus ponderosae Hopkins (Coleoptera: Curculionidae) in its native range in western Canada is lodgepole pine (Pinus contorta Dougl. var. latifolia Engelm.), but the insect is also capable of utilizing other species of pine, including jack pine (P. banksiana Lamb.) (Furniss and Schenk 1969; Safranyik and Linton 1982; Cerezke et al. 1995; Cullingham et al. 2011; Erbilgin et al. 2013). Lodgepole pine is found throughout northwestern North America, but occurs primarily in British Columbia (BC) and north-central Alberta, Canada. The northeastern portion of the range of lodgepole pine is contiguous with jack pine in Alberta. Jack pine extends east across Canada and into the northeastern United States (Little 1971). Where the two species' ranges overlap, they form a hybrid zone (Moss 1949), which in recent years has been successfully invaded by the mountain pine beetle (Langor et al. 2007). More recently, beetles have been found successfully reproducing in pure jack pine stands (Cullingham et al. 2011). Historically, mountain pine beetle populations have been most common west of the Rocky Mountains (Safranyik and Carroll 2006). Non-forested prairies, the high elevations of the mountains, and cold winters at higher latitudes have contributed to confining it to that distribution. Its recent invasion of the pine forests east of the Rocky Mountains in north-central Alberta (Langor et al. 2007; Cullingham et al. 2011) has raised concerns that it may have the capacity to spread eastward through Canada's extensive jack pine forest (Logan and Powell 2001; Safranyik et al. 2010). Invasion of a novel habitat by either a native or an alien herbivore may require that animal to exploit new host-plant populations or species. Release from competition and/or predation associated with the herbivore's native habitat are other factors that may 
contribute to the success of an invasive species (Keane and Crawley 2002). Encountering plants that are not able to defend themselves against specific forms of herbivory often enables an invading species to do well in a new environment. For instance, the emerald ash borer, Agrilus planipennis Fairmaire (Coleoptera: Buprestidae), an insect native to Asia where it is not considered a major pest, is very destructive to several species of ash (Fraxinus spp.) in North America (Haack et al. 2002; Poland and McCullough 2006). Asian ash species are more resistant to the emerald ash borer (Rebek et al. 2008), possibly due to significant differences in constitutive phloem chemistry, including compounds that are toxic or deterrent to other herbivores (Eyles et al. 2007).

In a similar fashion, mountain pine beetle invading previously unoccupied range may encounter hosts not adapted to defending against them, i.e., they enter relatively 'defense-free space' (Ghandi and Herms 2010). Cudmore et al. (2010) found that the productivity of beetles was higher in tree populations putatively naïve to mountain pine beetle outbreaks, but did not investigate potential mechanisms for this phenomenon. In northern Alberta, recent evidence for successful reproduction in jack pine (Cullingham et al. 2011) suggests the mountain pine beetle may be successful in these novel hosts, but the fitness and resultant dynamics of beetle populations in this new environment is presently unknown. Factors such as climate, the abundance and distribution of susceptible and suitable host trees, and overall stand structure may play key roles in determining the ultimate outcome of the spread into the jack pine forests. Since the susceptibility and suitability of a potential host tree to the mountain pine beetle is primarily a function of its chemistry (Safranyik and Carroll 2006) variation in tree chemistry in novel habitats will play a key role in determining the insect's success. 
Among the major defenses used by conifers against attacking organisms are their resin terpenes. Terpenes can serve as attractants or repellants for bark beetles (Gershenzon and Croteau 1991; Pureswaran and Borden 2003; Keeling and Bohlmann 2006) and have been implicated in host selection (Moeck and Simmons 1991). They have been found to be toxic to bark beetles (Smith 1961; Smith 1963; Smith 1965; Raffa et al. 1985), precursors to aggregation and anti-aggregation pheromones (Conn et al. 1984), and synergists to pheromones (Miller and Borden 1990; Borden et al. 1983; Conn et al. 1983). Resins are maintained in most conifers as a primary constitutive defense and produced as an induced defense, triggered when a tree is under attack (Raffa 1991). For example, lodgepole pine has been found to respond to attack by the mountain pine beetle and its associated fungi with large increases of total terpenes in the tree (Shrimpton 1973; Raffa and Berryman 1982; Raffa and Berryman 1983a; Miller et al. 1986; Boone et al. 2011). Similarly, in jack pine, total monoterpene concentrations have been found to be elevated in induced tissue compared to levels in constitutive tissue after attack by jack pine budworm (Wallin and Raffa 1999).

We compared the constitutive resin chemistry and induced responses to simulated attack between lodgepole pine in southern BC (where outbreaks are common) and northern BC (mainly outside of the historical range of the beetle) with those of jack pine in northern and central Alberta. Our objective was to compare the terpene defenses of lodgepole and jack pine trees to gain insight into the beetles' ability to locate suitable hosts, attract conspecifics, and use the resource to successfully reproduce in these new hosts. 


\section{METHODS AND MATERIALS}

Constitutive Defenses. Uninfested jack and lodgepole pine trees, as determined by the absence of pitch tubes and frass, were sampled along a transect from the Alberta/Saskatchewan border to Prince George, BC (Figure 1). We attempted to sample trees at even intervals along the transect, but large gaps where suitable pine could not be found due to agricultural or oil extraction activities, or natural breaks in the forest, could not be avoided. In 2006, seven locations were sampled. In 2007, an additional five sites were sampled to increase the total number of samples. A maximum of ten trees, each with a minimum diameter at breast height (d.b.h.; $1.3 \mathrm{~m}$ above the ground) of $15 \mathrm{~cm}$, were sampled per location. At some sites, ten trees meeting the minimum size requirements could not be found so fewer than ten trees were sampled (Figure 1). A $10 \mathrm{~mm}$ diameter punch (No. 149 Arch Punch 10 mm, C.S. Osborne \& Co., Harrison, N.J. 07029, U.S.A.) was used to remove a disk of bark and phloem at breast height. Each disk was stored in individually labeled envelopes and immediately placed into dry ice where it remained until transferred to a $-80^{\circ} \mathrm{C}$ freezer. Samples were kept at $-80^{\circ} \mathrm{C}$ until they were shipped, buried in dry ice, to the British Columbia Ministry of Forests and Range Forest Research Laboratory, Victoria, BC, for processing and analysis.

Phloem samples were processed using gas chromatographic-flame ionization detection analyses (GC-FID) to identify compounds by matching their retention time with synthetic standards. Samples were processed as described in Clark et al. (2010).

Based upon the location of the trees sampled in comparison with the sampling locations by Pollack and Dancik (1985), trees at each location were classified either as lodgepole or jack pine. Terpene concentrations ( $\mathrm{ppm}$ ) and the percent resin content of 
each terpene were analyzed using a two-sample non-parametric Wilcoxon rank sum test to determine if there were differences between the two species $(\alpha=0.05)$ as most of the terpene data could not be transformed to meet the assumption of homoscedasticity based upon a Levene's test. All data were analyzed using R v.2.6.2 (R Development Core Team 2008). Values below 5 ppm were considered to be zero for analysis.

Enantiomeric composition. To assess the enantiomeric composition of three of the predominant monoterpenes (limonene, $\alpha$-pinene, and $\beta$-pinene), samples from three populations - two lodgepole pine (BC) and one jack pine (Alberta) (Table 1) - taken in the same manner as previously described were analyzed. A Cyclodex-B column (Agilent Technologies) was used with helium as the carrier gas. All data for enantiomeric composition were analyzed using ANOVA with a Tukey's HSD post-hoc test $(\alpha=0.05)$. Data were transformed when necessary to meet assumptions of homoscedasticity based upon a visual examination of the residual plots.

Induced Defenses. Uninfested lodgepole pine trees, as determined by an absence of frass and pitch tubes, were selected in a stand near Chetwynd, BC (LP-N), located further north and east than recorded mountain pine beetle infestations prior to 1970 and near the northern edge of the historical range of mountain pine beetle (Safryanik and Carroll 2006), and near Kelowna, BC (LP-S). In addition, a stand of jack pine - a population assumed to be unexposed to mountain pine beetle - was selected near Fort McMurray, Alberta (JP) (Table 1). Two initial samples were taken by bark punch (10 mm diameter) from both the east and west side of the trees at breast height. Silicone plugs 
(Mack’s® Pillow Soft ${ }^{\circledR}$ silicone earplugs, McKeon Products, Inc. 25460 Guenther, Warren, MI) were used to cover the wound.

Prior to sampling the tree, the area where the bark punch was to be made was scraped to remove loose debris and then sprayed with ethanol (95\%). The tools used in the treatment and sampling process were also sprayed with ethanol before use on each tree to reduce potential contamination. The bark and phloem disks removed from each punch site were saved in individual, labeled envelopes and immediately buried in dry ice in a cooler, where it was kept until it could be transferred to a $-80^{\circ} \mathrm{C}$ freezer for longer-term storage prior to analysis.

Each pine was sampled in the same manner three times in August 2007: 1) the initial sample; 2) two days after initial sampling - with the sampling side randomly selected by a coin flip - approximately $10 \mathrm{~mm}$ above the initial punch wound; and 3) fourteen days after initial sampling on the side of the tree opposite from the two-day sample, again approximately $10 \mathrm{~mm}$ above the initial punch. The timing of the second sample at two days post-wounding was used because mass attack is normally completed in one or two days following contact of the first mountain pine beetle with the tree (Safranyik and Carroll 2006). Therefore, it is the initial response by the tree to wounding during this time that is most likely to have an effect on successful colonization.

Samples were shipped to the British Columbia Ministry of Forests and Range Forest Research Laboratory, Victoria, BC for processing using gas chromatographicflame ionization detection analysis exactly as described previously. One of the two initial phloem samples from each tree (from either east or west side of the tree) was selected by coin toss to be processed for comparison of induced levels of monoterpenes; the other 
sample was used for analysis of enantiomeric composition. Data on nine monoterpenes (3-carene, limonene, linalool, myrcene, $\beta$-phellandrene, $\alpha$-pinene, $\beta$-pinene, pulegone, terpinolene) and the total of all of the 26 terpenes measured were analyzed. Data were analyzed by analysis of variance (ANOVA) to compare monoterpene levels between locations at day 0,2 , and 14 . If required, data were transformed $\left[\log _{10}(x+1)\right]$ to meet requirements of homoscedasticity based on a visual examination of the residual plots. If the ANOVA was significant $(\alpha=0.05)$, means were separated by a post-hoc Tukey's HSD. Data were also analyzed to compare the rate of change in levels of each terpene between the sampling days using the Kruskal-Wallis non-parametric test followed by two sample non-parametric Wilcoxon rank sum test as data could not be transformed to meet requirements of homoscedasticity based on a visual examination of the residual plots.

\section{RESULTS}

Constitutive Defenses. Based upon the location of collection, we sampled 50 lodgepole pine trees and 61 jack pine trees. There was no significant difference in tree diameter between the two species in the sample population $(P>0.05)$. Pollack and Dancik (1985) found that $\alpha$-pinene and $\beta$-phellandrene were the most important variables for differentiating between lodgepole pine and jack pine and the putative hybrid populations in Alberta. With only one exception (which was analyzed as a jack pine), all of the trees sampled at sites considered to be occupied by jack pine had a higher percentage of $\alpha$-pinene compared with $\beta$-phellandrene; and all of the trees from sampling locations occupied by lodgepole pine had a higher percentage of $\beta$-phellandrene compared with $\alpha$-pinene. 
There were significant differences (Wilcoxon rank sum test, $\alpha=0.05$ ) between the constitutive concentrations (ppm) in lodgepole and jack pine for all but three of the 26 monoterpenes considered (Table 2). Of the monoterpenes that differed, lodgepole pine had higher levels of 20 of the 23 terpenes with the exceptions of: linalool, pulegone, and $\alpha$-pinene. Total terpenes were also higher in lodgepole pine than in jack pine. Lodgepole and jack pine also differed significantly in the percentage composition of all but five terpenes in the phloem resin (Table 3). In addition, lodgepole pine had a higher percent composition of all of the terpenes tested that differed between species, except for bornyl acetate $(0.37 \%$ vs. $1.80 \%), \alpha$-caryophyllene $(0.11 \%$ vs. $0.29 \%)$, pulegone $(0.24 \%$ vs. $4.16 \%)$, and $\alpha$-pinene (7.09\% vs. $58.42 \%)$.

Enantiomeric composition. There were significant differences between lodgepole and jack pine in the percent enantiomeric composition of limonene, $\alpha$-pinene, and $\beta$ pinene (Table 4). Both populations of lodgepole pine had significantly $(F=20.75 ; d f=$ $2,60 ; P<0.001)$ higher percentage of $(-)-\alpha$-pinene than the population of jack pine [and corresponding lower percentage of $(+)$ - $\alpha$-pinene $(F=20.57 ; d f=2,60 ; P<0.001)]$ (Table 4). Both populations of lodgepole pine and the jack pine population had higher percentages of the (-)-enantiomer of limonene than the (+)-enantiomer. The southern BC population of lodgepole pine near Kelowna had a higher percentage of $(+)$-limonene than the jack pine population $(F=4.87 ; d f=2,50 ; P=0.01)$, which conversely had higher percentage of $(-)$-limonene $(F=4.23 ; d f=2,50 ; P=0.02)$. All three populations of the two species contained exclusively (-)- $\beta$-pinene (Table 4). 
Induced Defenses. There were significant differences between the terpene levels sampled at day 0,2, and 14, and between the locations (Figure 2). There were also significant differences in the rate of change between locations for five of the terpenes: limonene, myrcene, $\alpha$-pinene, $\beta$-pinene, pulegone (Figure 3).

The southern BC lodgepole pine had a higher rate of increase in levels of limonene $\left(\chi^{2}=14.99 ; d f=2 ; P<0.001\right)$ between day 0 and 2 compared to the rates of increase in northern $\mathrm{BC}$ lodgepole pine and jack pine. The only difference $(F=4.25 ; d f=$ $2,28 ; P=0.02)$ in limonene levels between locations was in the initial sample between the northern BC lodgepole pine and the jack pine (Figure 2).

The northern BC lodgepole pine also had a lower rate of increase of myrcene levels $\left(\chi^{2}=10.92 ; d f=2 ; P<0.01\right)$ compared to the southern BC lodgepole pine, but neither lodgepole pine population differed from the jack pine between day 0 and 2. Only the initial sample had myrcene levels that were higher $(F=4.16 ; d f=2,28 ; P=0.03)$ in the northern BC lodgepole pine trees compared to the jack pine trees (Figure 2).

The rate of increase of $\alpha$-pinene levels in the southern BC lodgepole pine trees was higher $\left(\chi^{2}=10.35 ; d f=2 ; P<0.01\right)$ than in the northern BC lodgepole pine trees, while the rate of increase of $\alpha$-pinene levels in jack pine trees was not different from either population of lodgepole pine between day 0 and 2 (Figure 3). However, the absolute levels of $\alpha$-pinene were higher $(F=20.8 ; d f=2,28 ; P<0.001 ; F=13.68 ; d f=$ 2, 28; $P<0.001 ; F=45.46 ; d f=2,28 ; P<0.001)$ in jack pine on all three sample dates compared to both lodgepole pine populations (Figure 2). The rates of increase in $\beta$-pinene levels were higher $\left(\chi^{2}=12.90 ; d f=2 ; P<0.01\right)$ in jack pine and the southern $\mathrm{BC}$ lodgepole pine compared to the northern $\mathrm{BC}$ lodgepole pine from day 0 to 2 (Figure 3). 
The rate of increase in pulegone levels was higher $\left(\chi^{2}=16.93 ; d f=2 ; P<0.001\right)$ in the northern $\mathrm{BC}$ lodgepole pine compared to the jack pine and the level of pulegone was higher in the northern BC lodgepole pine compared with the other two sites (Figure 2). The level of pulegone in the southern BC lodgepole pine showed a significant rate of decrease compared with both other populations between day 0 and 2 (Figure 3 ) and the level was lower $(F=19.32 ; d f=2,28 ; P<0.001)$ than in northern BC lodgepole pine (Figure 2). Between day 2 and 14, jack pine showed a higher $\left(\chi^{2}=6.37 ; d f=2 ; P=0.04\right)$ rate of increase in pulegone compared to the southern BC lodgepole pine (Figure 3) although the levels at day 14 were not different between any of the locations (Figure 2).

There was no difference between locations in rate of change in the total phloem terpene levels, although the initial sample did show higher $(F=3.75 ; d f=2,28 ; P=0.04)$ levels of total terpenes in northern BC lodgepole pine compared to the jack pine. However, the levels of total terpenes were not different at day 2 or 14.

\section{DISCUSSION}

Comparison of bark resin terpene compositions of lodgepole and jack pine sampled in our study showed that lodgepole pine have higher constitutive levels of most terpenes than does jack pine, including 3-carene, myrcene, and terpinolene (Table 2). Many of these terpenes are important semiochemicals for the mountain pine beetle. For example, trap catches of mountain pine beetle in pheromone baited traps were enhanced by 3-carene released at a high rate (Miller and Borden 2000). Myrcene and terpinolene together were found to be an even more effective synergist than myrcene alone in pheromone baited traps (Borden et al. 2008), while myrcene was the most effective 
synergist in a baited tree study (Borden et al. 1983). This suggests that lodgepole pine may be more apparent than jack pine to foraging mountain pine beetles. On the other hand we found lower concentrations of the terpenes that are generally considered to be toxic - e.g., the ovicidal limonene and 3-carene (Raffa and Berryman 1983b) - in jack pine compared to lodgepole pine. As $\sim 47 \%$ of the jack pine in our study had undetectable levels of 3-carene, this host species is potentially more suitable than lodgepole pine for mountain pine beetle reproduction, although Erbilgin et al. (2013) found that jack pine released higher levels of 3-carene than lodgepole pine after beetle introduction. There is likely to be regional variation in the terpene composition of jack pine which could partially explain this difference between our observations and Erbilgin et al (2013) just as has been observed in lodgepole pine (Forrest 1980, Clark et al. 2010). Erbilgin et al. (2013) also used cut bolts rather than living trees which could further explain the discrepancies.

When considering our results it is important to remember that there is considerable regional variation in monoterpene composition among lodgepole pine populations (Forrest 1980; Smith 1983; Clark et al. 2010), and given the extensive historic range of the mountain pine beetle, it appears to have evolved to deal with this variation. Our sampling method does not allow us to account for any intraspecific variation in terpene levels as we are only separating by tree species. There is variation in terpene composition within the same tree species (Forrest 1980; Clark et al. 2010) but we focused on interspecific variation between the two pine species in this study.

The complex interactions between the insect and resin $\alpha$-pinene levels are very important in light of the fact that levels of this monoterpene in jack pine are significantly 
higher than in lodgepole pine (Table 1), thereby potentially affecting the mountain pine beetle's behavior and success in colonization of jack pine. $\alpha$-Pinene (Table 1) is metabolized by female mountain pine beetle to produce trans-verbenol, the primary component of the mountain pine beetle aggregation pheromone (Conn et al. 1984), which is essential to successful mass attack (Rudinsky 1962). Erbilgin et al. (2013) showed that the higher emissions of trans-verbenol by female mountain pine beetle on jack pine are associated with higher $\alpha$-pinene levels in that host. $\alpha$-Pinene is also auto-oxidized to verbenone, an anti-aggregation pheromone of the mountain pine beetle (Hunt et al. 1989), and Erbilgin et al. (2013) found equal amounts of verbenone emitted from lodgepole and jack pine bolts. Incorporating the host defenses into the chemical signals that regulate aggregation helps optimize the beetles' success (Raffa and Berryman 1983a).

The enantiomeric composition of $\alpha$-pinene can be important to some bark beetles (Renwick et al. 1976). Even though the overall levels of $\alpha$-pinene were higher in the jack pine, there was a lower proportion of (-)- $\alpha$-pinene compared with both populations of lodgepole pine (Table 4). Volatiles collected from bolts of lodgepole pine from southern BC showed $67.7 \%$ and $100 \%$ of (-)- $\alpha-$ and (-)- $\beta$-pinene respectively (Pureswaran et al. 2004), which corresponds well with our findings for the southern BC lodgepole pine bark and phloem (62.6\% and 100\% respectively) (Table 4). There is a correlation between the enantiomeric composition of $\alpha$-pinene the insects were exposed to and the ratio of pheromone enantiomers produced by several species of Ips (Seybold 1993). For example, a higher percentage of (-)- $\alpha$-pinene in the host spruce [Picea abies (L.) H. Karst.] was found to correlate with a higher percentage of cis-verbenol produced by Ips typographus (Lindström et al. 1989). We found significantly higher ratios of (-)- $\alpha$-pinene in jack pine 
compared to lodgpole pine which corresponds to findings by Erbiligin et al. (2013). Electroantennogram studies have shown that the mountain pine beetle can differentiate between enantiomers of verbenol and verbenone (Whitehead et al. 1989), although electrophysiological responses do not necessarily translate into specific behaviors and cis-verbenol was not as attractive as trans-verbenol to mountain pine beetles when combined with myrcene and exo-brevicomin (Miller and Lafontaine 1991). However Erbilgin et al. (2013) did not find the production of (-)-trans-verbenol to be limited by the enantiomeric composition of $\alpha$-pinene in the jack pine.

There were also differences in the rate of change in the levels of some terpenes after wounding, and if induced defensive responses are adequate and rapid beetles will sometimes abandon their colonization attempts (Raffa 1991). Uninfested lodgepole pine trees near Kelowna, $\mathrm{BC}$ were hard to find due to the high level of beetle activity in that area. While the sampled trees were uninfested, likely due to chance or geographic distance from infested stands, it is also possible that they may have possessed some characteristic that made them relatively unsuitable for colonization. Furthermore, in an attempt to standardize the levels of observed induced defenses these trees were only mechanically wounded as there is large variability between the beetles and the microorganisms they carry (Lee et al. 2006). Our results could therefore be different than the induced response that would be caused by beetle attack.

Limonene, a terpene toxic to bark beetles (Smith 1965; Raffa and Berryman 1983b; Cook and Hain 1988), was found to have a higher rate of increase between day 0 and day 2 in the southern population of lodgepole pine compared with the northern lodgepole pine population. This stronger response by the southern lodgepole pine after 
wounding compared with the northern pine trees supports the hypothesis that tree populations with more prior exposure to mountain pine beetle outbreaks maintain a more effective response to attack - i.e., rapid increase in levels of a toxic terpene - and hence are also less suitable for reproduction (Cudmore et al. 2010). The rate of increase of myrcene as well as the levels and rate of increase of $\beta$-pinene, did not differ between southern lodgepole pine and jack pine, which indicates that the beetle would experience a similar rate of response in this new host species for these terpenes.

The outcome of the interaction of the mountain pine beetle with phloem resin constituents in a novel host such as jack pine could also be dependent on beetle population levels. Boone et al. (2011) found that the resin defenses in lodgepole pine play an important role in protecting trees from mountain pine beetle attack at low population levels but not at high populations. Our results suggest that due to the generally lower levels of terpene-based defenses in jack pine relative to lodgepole pine, incipientepidemic populations of mountain pine beetles may have a greater success in colonizing jack pine. Furthermore, beetles may be able to exploit the relatively higher levels of $\alpha$ pinene in jack pine to produce aggregation pheromones that further increase colonization success (Erbilgin et al. 2013) and allow populations to increase rapidly.

Cullingham et al. (2012) predicted the distribution of lodgepole and jack pine using genetic information. Their work indicates that the range of pure jack pine begins further east than the historical range given by Little (1971). Based on Cullingham et al. (2012) we may have sampled trees that we have identified as jack pine in this study that are not necessarily considered pure. However, we have shown that the mountain pine beetle is moving into an area that has significant differences in the absolute and relative 
terpene levels regardless of the hybrid-genetic status of the hosts that they encounter. Most studies on the behavioral and toxic effects of terpenes on mountain pine beetle are conducted using lodgepole or ponderosa pine (Pinus ponderosa Dougl. ex Laws.) as model host species. The minimum levels of resin terpenes necessary to provide an adequate attractant plume from an attacked bole are not known. Therefore there could be an additive effect between a number of host kairomones (Borden et al. 1983; Conn et al. 1983), which in combination with the higher levels of total terpenes present in lodgepole pine may suggest that lodgepole pine are easier for mountain pine beetle to locate than jack pine. The terpene composition may also make the lodgepole pine easier to identify as a suitable host. For example, despite what appears to be a preferable chemical environment in a novel host, whitebark pine (Pinus albicaulis), compared to lodgepole pine, Raffa et al. (2013) found that mountain pine beetle did not show preference for whitebark pine in mixed stands, indicating that mountain pine beetle may be better at recognizing its traditional host in such situations. However, the combination of lower levels of some terpenes generally considered toxic to insects, and an increased concentration of $\alpha$-pinene, which is a precursor of both the primary aggregation and antiaggregation pheromones, may make jack pine easier to attack and colonize. This implies a substantial potential for ongoing and increased success for the mountain pine beetle in this new geographic range and host, particularly if climatic suitability increases as predicted (Safranyik and Carroll 2006, Safranyik et al. 2010). As the beetle spreads further into pure jack pine forests, it will be critical to conduct further research into the behavior and reproductive success of mountain pine beetle in this new host. 


\section{ACKNOWLEDGEMENTS}

Analytical chemistry analyses on phloem samples were performed by Mr. Clive Dawson of the British Columbia Ministry of Forests, Lands and Natural Resources Operations.

\section{REFERENCES}

BIRGERSSON, G. and LEUFVÉN, A. 1988. The influence of host tree response to Ips typographus and fungal attack on production of semiochemicals. Insect Biochem. 18: 761-770.

BOONE, C.K., AUKEMA, B.H., BOHLMANN, J., CARROLL, A.L., and RAFFA, K.F. 2011. Efficacy of tree defense physiology varies with bark beetle population density: a basis for positive feedback in eruptive species. Can. J. For. Res. 41: 1174-1188. BORDEN, J.H., PURESWARAN, D.S., and LAFONTAINE, J.P. 2008. Synergistic blends of monoterpenes for aggregation pheromones of the mountain pine beetle (Coleoptera: Curculionidae). J. Econ. Entomol. 101: 1266-1275.

BORDEN, J.H., CONN, J.E., FRISKIE, L.M., SCOTT, B.E., CHONG, L.J., PIERCE, H.D.J., and OEHLSCHLAGER, A.C. 1983. Semiochemicals for the mountain pine beetle, Dendroctonus ponderosae (Coleoptera: Scolytidae), in British Columbia: Baitedtree studies. Can. J. For. Res. 13: 325-333.

CEREZKE, H.F. 1995. Egg gallery, brood production, and adult characteristics of mountain pine beetle, Dendroctonus ponderosae Hopkins (Coleoptera: Scolytidae), in three pine hosts. Can. Entomol. 127: 955-964.

CLARK, E.L., CARROLL, A.L., and HUBER, D.P.W. 2010. Differences in the constitutive terpene profile of lodgepole pine across a geographical range in British 
Columbia, and correlation with historical attack by mountain pine beetle. Can. Entomol. 142: 1-17.

COOK, S.P. and HAIN, F.P. 1988. Toxicity of host monoterpenes to Dendroctonus frontalis and Ips calligraphus (Coleoptera: Scolytidae). J. Entomol. Sci. 23: 287-292. CONN, J.E., BORDEN, J.H., SCOTT, B.E., FRISKIE, L.M., PIERCE, H.D., Jr., and OEHLSCHLAGER, A.C. 1983. Semiochemicals for the mountain pine beetle, Dendroctonus ponderosae (Coleoptera: Scolytidae) in British Columbia: Field trapping studies. Can. J. For. Res. 13: 320-324.

CONN, J.E., BORDEN, J.H., HUNT, D.W.A., HOLMAN, J., WHITNEY, H.S., SPANIER, O.J., PIERCE, H.D., Jr., and OEHLSCHLAGER, A.C. 1984. Pheromone production by axenically reared Dendroctonus ponderosae and Ips paraconfusus (Coleoptera:Scolytidae). J. Chem. Ecol. 10: 281-290.

CUDMORE, T.J., BJÖRKLUND, N., CARROLL, A.L., and LINDGREN, B.S. 2010. Climate change and range expansion of an aggressive bark beetle: evidence of higher reproductive success in naïve host tree populations. J. Appl. Ecol. 47: 1036-1043. CULLINGHAM, C.I., JAMES, P.M.A., COOKE, J.E.K., and COLTMAN, D.W. 2012. Characterizing the physical and genetic structure of the lodgepole pine $\mathrm{x}$ jack pine hybrid zone: mosaic structure and differential introgression. Evol. Appl. 5: 879-891 doi:

$10.1111 / \mathrm{j} .1752-4571.2012 .00266 . \mathrm{x}$

CULLINGHAM, C.I., COOKE, J.E.K., DANG, S., DAVIS, C.S., COOKE, B.J., and COLTMAN, D.W. 2011. Mountain pine beetle host-range expansion threatens the boreal forest. Mol. Ecol. 20:1-15. 
ERBILGIN, N., WHITEHOUSE, C., SHAN, B., NAJAR, A. and EVENDEN, M. 2013. Chemical similarity between historical and novel host plants promotes range and host expansion of the mountain pine beetle in a naïve host ecosystem. New Phytol. doi: 10.1111/nph.12573: 1-11.

EYLES, A., JONES, W., RIEDLE, K., CIPOLLINI, D., SCHWARTZ, S., CHAN, K., HERMS, D.A., and BONELLO, P. 2007. Comparative phloem chemistry of Manchurian (Fraxinus mandshurica) and two North American ash species (Fraxinus americana and Fraxinus pennsylvanica). J. Chem. Ecol. 33: 1430-1448.

FORREST, G.I. 1980. Geographic variation in the monoterpenes of Pinus contorta oleoresin. Biochem. Syst. Ecol. 8: 343-359.

FURNISS, M.M. and SCHENK, J.A. 1969. Sustained natural infestation by the mountain pine beetle in seven new Pinus and Picea hosts. J. Econ. Entomol. 62: 518-519. GERSHENZON, J. and CROTEAU, R.B. 1991. Terpenoids, pp. 165-219, in G.A. Rosenthal and M.R. Berembaum (eds.). Herbivores: Their interactions with secondary plant metabolites. CRC Press, New York.

GHANDI, K.J.K. and HERMS, D.A. 2010. Direct and indirect effects of alien insect herbivores on ecological processes and interactions in forest of eastern North America. Biol. Inv. 12: 389-405.

HAACK, R.A., JENDEK, E., LIU, H., MARCHANT, K.R., PETRICE, T.R., POLAND, T.M., and YE, H. 2002. The emerald ash borer: A new exotic pest in North America. Newsletter of the Michigan Entomological Society. 47: 1-5. 
HUNT, D.W.A., BORDEN, J.H., LINDGREN, B.S., and GRIES, G. 1989. The role of autoxidation of $\alpha$-pinene in the production of pheromones of Dendroctonus ponderosae (Coleoptera: Scolytidae). Can. J. For. Res. 19: 1275-1282.

KEANE, R.M. and CRAWLEY, M.J. 2002. Exotic plant invasions and the enemy release hypothesis. Trends Ecol. Evol. 117: 164-170.

KEELING, C.I. and BOHLMANN, J. 2006. Genes, enzymes and chemicals of terpenoid diversity in the constitutive and induced defense of conifers against insects and pathogens. New Phytol. 170: 657-675.

LANGOR, D., RICE, A., and WILLIAMS, D. 2007. Mountain pine beetle invasion of boreal forests. Canadian Silviculture. February: 5-7.

LEE, S., KIM, J.-J., and BREUIL, C. 2006. Diversity of fungi associated with the mountain pine beetle, Dendroctonus ponderosae and infested lodgepole pines in British Columbia. Fungal Divers. 22: 91-105.

LINDSTRÖM, M., NORIN, T., BIRGERSSON, G., and SCHLYTER, F. 1989. Variation of enantiomeric composition of $\alpha$-pinene in Norway spruce, Picea abies, and its influence on production of verbenol isomers by Ips typographus in the field. J. Chem. Ecol. 15: $541-548$.

LITTLE Jr., E.L. 1971. Atlas of United States trees. Volume 1: conifers and important hardwoods. US Department of Agriculture Miscellaneous Publication 1146. Washington, DC., USA.

LOGAN, J.A. and POWELL, J.A. 2001. Ghost forests, global warming, and the mountain pine beetle (Coleoptera: Scolytidae). Amer. Entomol. 47: 160-172. 
MILLER, D.R. and LAFONTAINE, J.P. 1991. cis-Verbenol: An aggregation pheromone for the mountain pine beetle, Dendroctonus ponderosae Hopkins (Coleoptera:

Scolytidae). J. Entomol. Soc. Brit. Columbia 88: 34-38.

MILLER, D.R. and BORDEN, J.H. 2000. Dose-dependent and species-specific response of pine bark beetles (Coleoptera: Scolytidae) to monoterpenes in association with pheromones. Can. Entomol. 132: 183-195.

MILLER, D.R. and BORDEN, J.H. 1990. $\beta$-Phellandrene: Kairomone for pine engraver, Ips pini (Say) (Coleoptera: Scolytidae). J. Chem. Ecol. 16: 2519-2531.

MILLER, R.H., BERRYMAN, A.A., and RYAN, C.A. 1986. Biotic elicitors of defense reactions in lodgepole pine. Phytochem. 25: 611-612.

MOECK, H.A. and SIMMONS, C.S. 1991. Primary attraction of mountain pine beetle, Dendroctonus ponderosae Hopk. (Coleoptera: Scolytidae), to bolts of lodgepole pine. Can. Entomol. 123: 299-304.

MOSS, E.H. 1949. Natural pine hybrids in Alberta. Can. J. Res., Section C, Bot. Sci. 27: 218-229.

POLAND, T.M. and MCCULLOUGH, D.G. 2006. Emerald ash borer: Invasion of the urban forest and the treat to North America's ash resource. J. For. 104: 118-124.

POLLACK, J.C. and DANCIK, B.P. 1985. Monoterpene and morphological variation and hybridization of Pinus contorta and P. banksiana in Alberta. Can. J. Bot. 63: 201210.

PURESWARAN, D.S. and BORDEN, J.H. 2003. Test of semiochemical mediated host specificity in four species of tree killing bark beetles (Coleoptera: Scolytidae). Environ. Entomol. 32: 963-969. 
PURESWARAN, D.S., GRIES, R., and BORDEN, J.H. 2004. Quantitative variation in monoterpenes in four species of conifers. Biochem. System. Ecol. 32: 1109-1136.

R DEVELOPMENT CORE TEAM. 2008. R: A language and environment for statistical computing. R Foundation for Statistical Computing, Vienna, Austria. ISBN 3-900051-070, URL http://www.R-project.org

RAFFA, K.F. 1991. Induced defensive reactions in conifer-bark beetle systems, pp. 245276, in D.W. Tallamy and M.J. Raupp (eds.). Phytochemical induction by herbivores. John Wiley and Sons, Inc., Academic Press, New York.

RAFFA, K.F. and BERRYMAN, A.A. 1982. Physiological differences between lodgepole pines resistant and susceptible to the mountain pine beetle and associated microorganisms. Environ. Entomol. 11: 486-492.

RAFFA, K.F. and BERRYMAN, A.A. 1983a. The role of host plant resistance in the colonization behavior and ecology of bark beetles (Coleoptera: Scolytidae). Ecol. Monogr. 53: 27-49.

RAFFA, K.F. and BERRYMAN, A.A. 1983b. Physiological aspects of lodgepole pine wound responses to a fungal symbiont of the mountain pine beetle, Dendroctonus ponderosae (Coleoptera: Scolytidae). Can. Entomol. 115: 723-734.

RAFFA, K.F. and BERRYMAN, A.A. 1987. Interacting selective pressures in coniferbark beetle systems: A basis for reciprocal adaptations? Amer. Natur. 129: 234-262.

RAFFA, K.F., POWELL, E.N., and TOWNSEND, P.A. 2013. Temperature-driven range expansion of an irruptive insect heightened by weakly coevolved plant defenses. Proc. Natl. Acad. Sci. U.S.A. 110: 2193-2198. 
RAFFA, K.F., BERRYMAN, A.A., SIMASKO, J., TEAL, W., and WONG, B.L. 1985. Effects of grand fir monoterpenes on the fir engraver Scolytus ventralis (Coleoptera: Scolytidae) and its symbiotic fungus. Environ. Entomol. 14: 552-556.

REBEK, E.J., HERMS, D.A., and SMITLEY, D.R. 2008. Interspecific variation in resistance to emerald ash borer (Coleoptera: Buprestidae) among North American and Asian ash (Fraxinus spp.). Environ. Entomol. 37: 242-246.

RENWICK, J.A.A., HUGHES, P.R., and KRULL, I.S. 1976. Selective production of cisand trans-verbenol from (-)- and (+)- $\alpha$-pinene by a bark beetle. Science 191:199-201. RUDINSKY, J.A. 1962. Ecology of scolytidae. Annu. Rev. Entomol. 7: 327-348. SAFRANYIK, L. and CARROLL, A.L. 2006. The biology and epidemiology of the mountain pine beetle in lodgepole pine forests, pp. 3-66, in L. Safranyik, and W.R. Wilson (eds.). The mountain pine beetle: A synthesis of biology, management, and impacts on lodgepole pine. Natural Resources Canada, Canadian Forest Service, Pacific Forestry Centre, Victoria, British Columbia.

SAFRANYIK, L. and LINTON, D.A. 1982. Survival and development of mountain pine beetle broods in jack pine bolts from Ontario. Can. For. Serv. Res. Note 2: 17-18

SAFRANYIK, L., CARROLL, A.L., RÉGNIÈRE, J., LANGOR, D.W., RIEL, W.G., SHOREM, T.L., PETER, B., COOKE, B.J., NEALIS, V.G., and TAYLOR, S.W. 2010. Potential for range expansion of mountain pine beetle into the boreal forest of North America. Can. Entomol. 142: 415-442.

SEYBOLD, S.J. 1993. Role of chirality in olfactory-directed behavior: Aggregation of pine engraver beetles in the genus Ips (Coleoptera: Scolytidae). J. Chem. Ecol. 19: 18091831. 
SHRIMPTON, D.M. 1973. Extractives associated with wound response of lodgepole pine attacked by the mountain pine beetle and associated microorganisms. Can. J. Bot. 51: $527-534$

SMITH, R.H. 1961. The fumigant toxicity of three pine resins to Dendroctonus brevicomis and D. jeffreyi. J. Econ. Entomol. 54: 365-369.

SMITH, R.H. 1963. Toxicity of pine resin vapors to three species of Dendroctonus bark beetles. J. Econ. Entomol. 56: 827-831.

SMITH, R.H. 1965. Effect of monoterpene vapors on the western pine beetle. J. Econ. Entomol. 58: 509-510.

SMITH, R.H. 1983. Monoterpenes of lodgepole pine xylem resin: a regional study in Western United States. Forest Sci. 29: 333-340.

WALLIN, K.F. and RAFFA, K.F. 1999. Altered constitutive and inducible phloem monoterpenes following natural defoliation of jack pine: Implications to host mediated interguild interactions and plant defense theories. J. Chem. Ecol. 25: 861-880.

WHITEHEAD, A.T., SCOTT, D.T., SCHMITZ, R.F., and MORI, K. 1989. Electroantennograms by mountain pine beetles, Dendroctonus ponderosae Hopkins, exposed to selected chiral semiochemicals. J. Chem. Ecol. 15: 2089-209. 


\section{Figure 1}

Map of sample locations in BritishColumbia and Alberta.

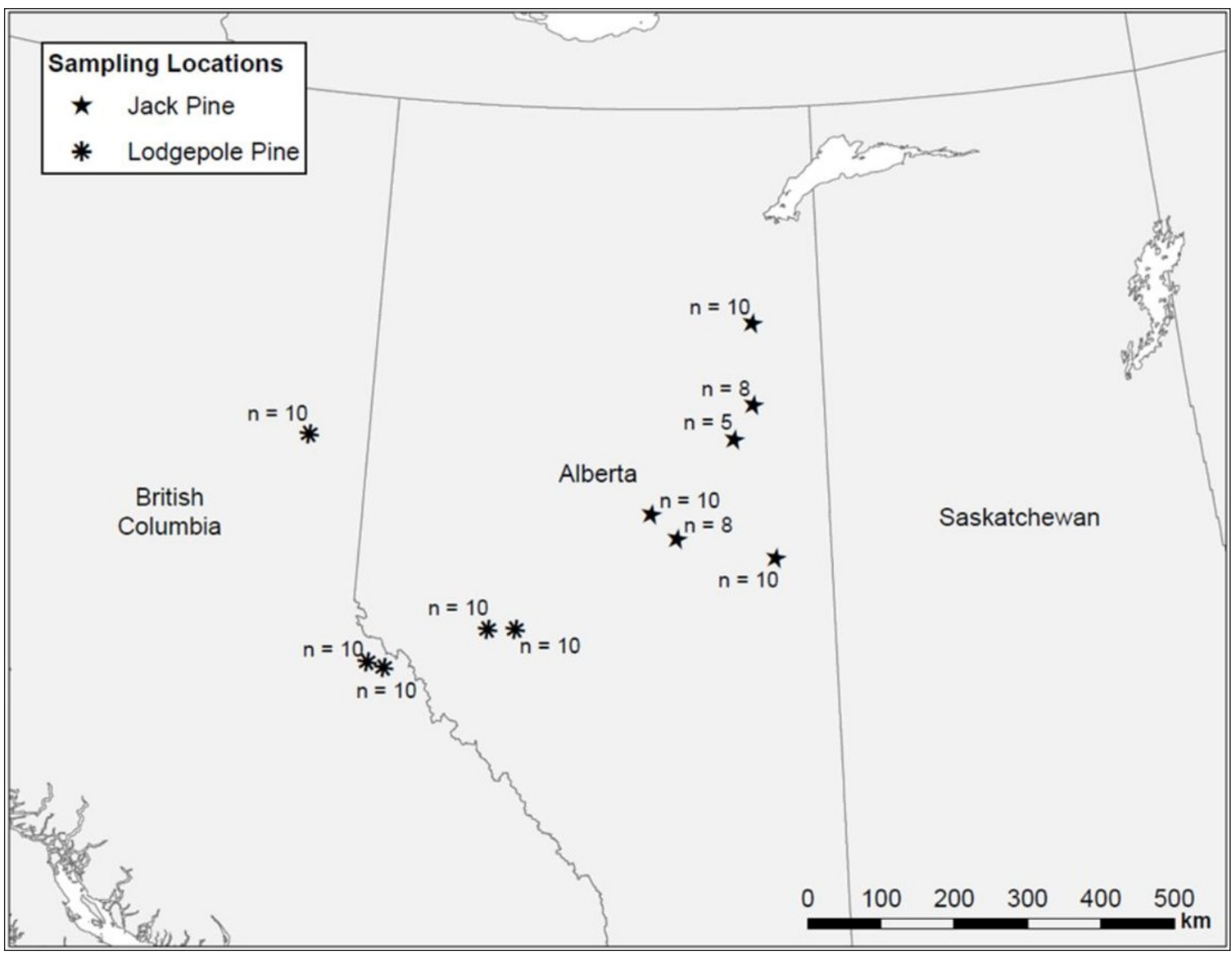




\section{Table 1 (on next page)}

Sampling locations (Kelowna and Chetwynd -lodgepole pine, Fort McMurray - jack pine), number of trees sampled at eachlocation, and dates of sampling for work on induced defenses 


\begin{tabular}{lllllll}
\hline & \# of & & \multicolumn{4}{c}{ Dates Sampled } \\
\cline { 4 - 7 } Location & trees & Coordinates & Day 0 & Day 2 & Day 14 \\
\hline Kelowna & 10 & $\mathrm{~N}$ & $\mathrm{~W}$ & 01 Aug 07 & 03 Aug 07 & 15 Aug 07 \\
& & $49^{\circ} 57.684^{\prime}$ & $119^{\circ} 42.551^{\prime}$ & & & \\
Chetwynd & 11 & $\mathrm{~N}$ & $\mathrm{~W}$ & 05 Aug 07 & 07 Aug 07 & 19 Aug 07 \\
& & $49^{\circ} 53.145^{\prime}$ & $120^{\circ} 25.121^{\prime}$ & & & \\
Fort & 10 & $\mathrm{~N}$ & $\mathrm{~W}$ & 09 Aug 07 & 11 Aug 07 & 23 Aug 07 \\
McMurray & & $57^{\circ} 21.640^{\prime}$, & $111^{\circ} 32.281^{\prime}$ & & & \\
\hline
\end{tabular}




\section{Table 2 (on next page)}

Mean content of terpenes (PPM) ( \pm 1 SE) oflodgepole and jack pine trees 


\begin{tabular}{|c|c|c|c|}
\hline \multirow[b]{2}{*}{ Terpene } & \multirow[b]{2}{*}{$P$-value ${ }^{\text {a }}$} & \multicolumn{2}{|c|}{ Mean content (ppm) } \\
\hline & & Lodgepole pine & Jack pine \\
\hline Borneol & $P<0.001$ & $14.67 \pm 3.18$ & $4.18 \pm 1.64$ \\
\hline Bornyl Acetate & $P=0.004$ & $45.95 \pm 12.55$ & $42.52 \pm 3.41$ \\
\hline Camphene & $P<0.001$ & $88.47 \pm 8.30$ & $30.32 \pm 4.51$ \\
\hline Camphor & $P=0.041$ & $6.69 \pm 1.93$ & $2.21 \pm 0.85$ \\
\hline 3-Carene & $P<0.001$ & $1738.14 \pm 321.80$ & $226.99 \pm 44.95$ \\
\hline$\alpha$-Caryophyllene & $P<0.001$ & $16.02 \pm 3.32$ & $5.47 \pm 2.24$ \\
\hline$\alpha$-Copaene & $P<0.001$ & $13.70 \pm 2.68$ & $1.09 \pm 0.78$ \\
\hline$\alpha$-Cubebene & $P=0.273$ & $2.50 \pm 1.46$ & $0.79 \pm 0.63$ \\
\hline p-Cymene & $P<0.001$ & $32.06 \pm 5.11$ & $2.90 \pm 1.71$ \\
\hline$\alpha$-Humulene & $P<0.001$ & $42.35 \pm 7.30$ & $3.19 \pm 1.42$ \\
\hline Limonene & $P<0.001$ & $848.64 \pm 164.35$ & $203.25 \pm 48.89$ \\
\hline Linalool & $P=0.220$ & $64.73 \pm 9.02$ & $117.74 \pm 16.68$ \\
\hline Myrcene & $P<0.001$ & $435.45 \pm 45.48$ & $100.18 \pm 15.71$ \\
\hline Ocimene & $P<0.001$ & $31.75 \pm 8.21$ & $0.00 \pm 0.00$ \\
\hline$\alpha$-Phellandrene & $P<0.001$ & $175.77 \pm 17.93$ & $1.62 \pm 1.38$ \\
\hline$\beta$-Phellandrene & $P<0.001$ & $9096.72 \pm 960.59$ & $157.21 \pm 40.39$ \\
\hline$\alpha$-Pinene & $P<0.001$ & $949.81 \pm 132.72$ & $2518.14 \pm 328.27$ \\
\hline$\beta$-Pinene & $P<0.001$ & $921.46 \pm 127.02$ & $283.98 \pm 43.68$ \\
\hline Pulegone & $P=0.039$ & $30.21 \pm 6.81$ & $107.13 \pm 22.81$ \\
\hline Sabinene & $P<0.001$ & $141.94 \pm 17.74$ & $7.12 \pm 2.17$ \\
\hline$\alpha$-Terpinene & $P<0.001$ & $15.39 \pm 2.95$ & $0.00 \pm 0.00$ \\
\hline$\gamma$-Terpinene & $P<0.001$ & $23.81 \pm 5.42$ & $0.00 \pm 0.00$ \\
\hline Terpineol & $P<0.001$ & $53.64 \pm 8.55$ & $16.50 \pm 6.59$ \\
\hline Terpinolene & $P<0.001$ & $352.79 \pm 48.44$ & $47.07 \pm 13.04$ \\
\hline$\alpha$-Thujone & $P=0.122$ & $2.25 \pm 0.84$ & $1.85 \pm 1.20$ \\
\hline Total & $P<0.001$ & $15144.92 \pm 1463.47$ & $3881.44 \pm 395.26$ \\
\hline
\end{tabular}

${ }^{a}$ Differences between species as determined by a Wilcoxon rank sum test $(\alpha=0.05$, significant differences in bold). 


\section{Table 3 (on next page)}

Mean relative contentof terpenes (\%) ( $\pm 1 \mathrm{SE}$ ) of lodgepoleand jack pine 


\begin{tabular}{|c|c|c|c|}
\hline \multirow[b]{2}{*}{ Terpene } & \multirow[b]{2}{*}{$P$-value ${ }^{\mathrm{a}}$} & \multicolumn{2}{|c|}{$\begin{array}{c}\text { Mean relative content } \\
\text { (\% of total monoterpenes })\end{array}$} \\
\hline & & Lodgepole pine & Jack pine \\
\hline Borneol & $P=0.016$ & $0.11 \pm 0.02$ & $0.09 \pm 0.03$ \\
\hline Bornyl Acetate & $P<0.001$ & $0.37 \pm 0.10$ & $1.80 \pm 0.26$ \\
\hline Camphene & $P=0.874$ & $0.64 \pm 0.09$ & $0.60 \pm 0.08$ \\
\hline Camphor & $P=0.120$ & $0.06 \pm 0.03$ & $0.07 \pm 0.03$ \\
\hline 3-Carene & $P=0.005$ & $10.56 \pm 1.33$ & $8.68 \pm 1.48$ \\
\hline$\alpha$-Caryophyllene & $P<0.001$ & $0.11 \pm 0.03$ & $0.29 \pm 0.14$ \\
\hline$\alpha$-Copaene & $P<0.001$ & $0.09 \pm 0.02$ & $0.02 \pm 0.01$ \\
\hline$\alpha$-Cubebene & $P=0.307$ & $0.01 \pm 0.01$ & $0.04 \pm 0.04$ \\
\hline p-Cymene & $P<0.001$ & $0.20 \pm 0.04$ & $0.07 \pm 0.04$ \\
\hline$\alpha$-Humulene & $P<0.001$ & $0.32 \pm 0.06$ & $0.18 \pm 0.12$ \\
\hline Limonene & $P=0.004$ & $5.26 \pm 0.85$ & $4.77 \pm 0.99$ \\
\hline Linalool & $P=0.090$ & $0.87 \pm 0.38$ & $5.93 \pm 1.37$ \\
\hline Myrcene & $P=0.005$ & $2.98 \pm 0.28$ & $2.16 \pm 0.28$ \\
\hline Ocimene & $P<0.001$ & $0.18 \pm 0.05$ & $0.00 \pm 0.00$ \\
\hline$\alpha$-Phellandrene & $P<0.001$ & $1.13 \pm 0.07$ & $0.02 \pm 0.02$ \\
\hline$\beta$-Phellandrene & $P<0.001$ & $58.25 \pm 1.92$ & $4.19 \pm 0.99$ \\
\hline$\alpha$-Pinene & $P<0.001$ & $7.09 \pm 0.91$ & $58.42 \pm 2.32$ \\
\hline$\beta$-Pinene & $P=0.687$ & $6.74 \pm 0.77$ & $6.47 \pm 0.72$ \\
\hline Pulegone & $P<0.001$ & $0.24 \pm 0.06$ & $4.16 \pm 1.23$ \\
\hline Sabinene & $P<0.001$ & $0.91 \pm 0.09$ & $0.19 \pm 0.06$ \\
\hline$\alpha$-Terpinene & $P<0.001$ & $0.08 \pm 0.02$ & $0.00 \pm 0.00$ \\
\hline$\gamma$-Terpinene & $P<0.001$ & $0.11 \pm 0.02$ & $0.00 \pm 0.00$ \\
\hline Terpineol & $P<0.001$ & $0.37 \pm 0.06$ & $0.30 \pm 0.12$ \\
\hline Terpinolene & $P<0.001$ & $3.29 \pm 1.02$ & $1.32 \pm 0.35$ \\
\hline$\alpha$-Thujone & $P=0.128$ & $0.02 \pm 0.01$ & $0.20 \pm 0.14$ \\
\hline
\end{tabular}

${ }^{\mathrm{a}}$ Differences between species as determined by a two-sample Wilcoxon test $(\alpha=0.05$, significant differences in bold). 


\section{Table 4 (on next page)}

Mean percentages of chiral monoterpenes $( \pm 1 \mathrm{SE}$ ) fromlodgepole pine trees in northern and southern locations (LP-N and LP-Srespectively) and jack pine trees (JP) a 


\begin{tabular}{|c|c|c|c|c|c|c|}
\hline Location & $\begin{array}{l}(+)-\alpha- \\
\text { pinene }\end{array}$ & $\begin{array}{l}(-)-\alpha- \\
\text { pinene }\end{array}$ & $\begin{array}{l}(+)-\beta- \\
\text { pinene }\end{array}$ & $\begin{array}{c}(-)-\beta- \\
\text { pinene }\end{array}$ & $\begin{array}{l}(\mathrm{R})-(+)- \\
\text { limonene }\end{array}$ & $\begin{array}{l}(\mathrm{S})-(-)- \\
\text { limonene }\end{array}$ \\
\hline LP-S & $\begin{array}{c}37( \pm 4) \\
\mathrm{n}=28\end{array}$ & $\begin{array}{c}63( \pm 4) \\
\mathrm{n}=28\end{array}$ & $\begin{array}{c}0 \\
\mathrm{n}=28\end{array}$ & $\begin{array}{c}100 \\
n=28\end{array}$ & $\begin{array}{c}29( \pm 5) \\
\mathrm{n}=27\end{array}$ & $\begin{array}{c}71( \pm 5) \\
n=27\end{array}$ \\
\hline LP-N & $\begin{array}{c}50( \pm 6) \\
n=17\end{array}$ & $\begin{array}{c}50( \pm 6) \\
n=17\end{array}$ & $\begin{array}{c}0 \\
\mathrm{n}=16\end{array}$ & $\begin{array}{c}100 \\
n=16\end{array}$ & $\begin{array}{c}17( \pm 5) \\
n=16\end{array}$ & $\begin{array}{c}83( \pm 5) \\
n=16\end{array}$ \\
\hline JP & $\begin{array}{c}78( \pm 4) \\
n=18\end{array}$ & $\begin{array}{c}22( \pm 4) \\
\mathrm{n}=18\end{array}$ & $\begin{array}{c}0 \\
\mathrm{n}=14\end{array}$ & $\begin{array}{c}100 \\
\mathrm{n}=14\end{array}$ & $\begin{array}{l}5( \pm 5) \\
\mathrm{n}=10\end{array}$ & $\begin{array}{c}95( \pm 5) \\
\mathrm{n}=10\end{array}$ \\
\hline
\end{tabular}

${ }^{a}$ Number of samples for each compound and location varied due to sample failures. 


\section{Figure 2}

Mean levels of terpenes at day 0 (initialsample), day 2, and day 14 in two populations of lodgepole pine (LP -S -southern lodgepole pine, Kelowna; LP-N - northern lodgepole pine, Chetwynd) andone population of jack pine (JP - Fort McMurray) in response to
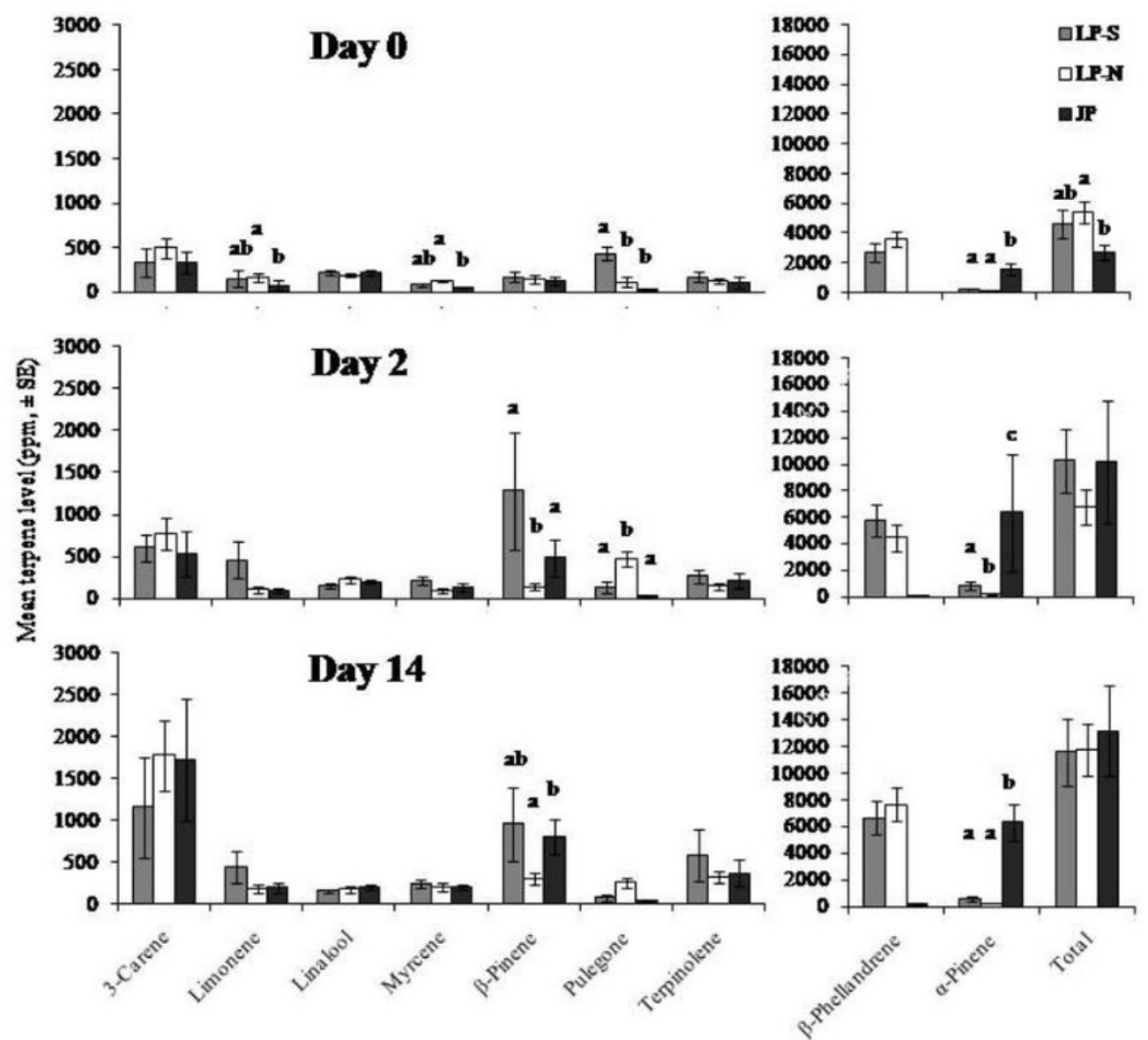


\section{Figure 3}

Change in terpene levels at day 0 , day 2, andday 14 in two populations of lodgepole pine (LP-S - southern lodgepole pine,Kelowna; LP-N - northern lodgepole pine, Chetwynd) and one population of jackpine (JP - Fort McMurray) in response to wounding. Asteri

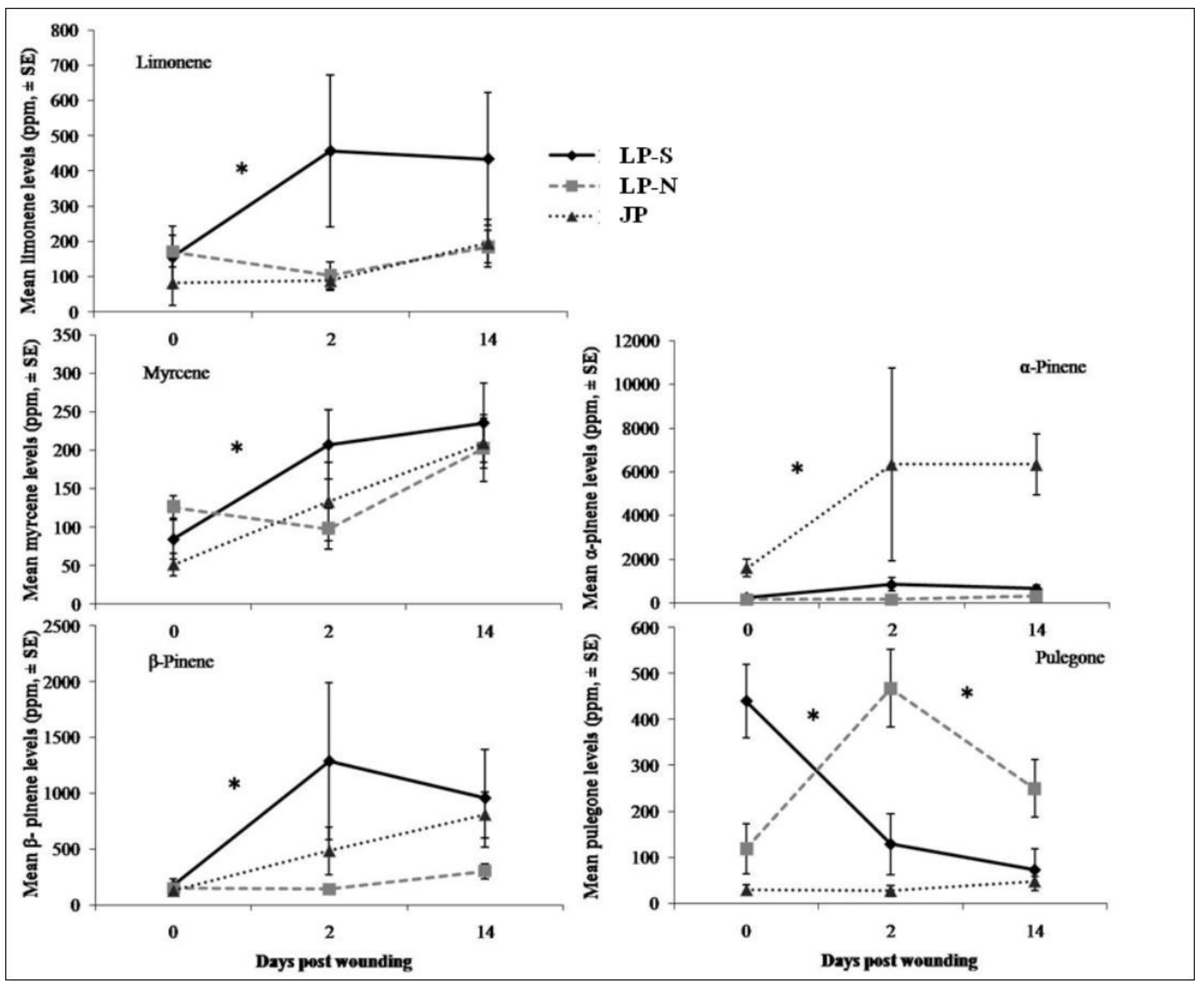

